\title{
Effects of ethanolic extract of leaves of Lafoensia pacari A. St.-Hil., Lythraceae (pacari), in pain and inflammation models
}

\author{
Heloisa Alves Guimarães, ${ }^{1}$ Marcus Vinícius M. Nascimento, ${ }^{1}$ Adriano Tavares, ${ }^{1}$ \\ Pablinny Moreira Galdino, ${ }^{1}$ José Realino de Paula, ${ }^{2}$ Elson Alves Costa ${ }^{*}, 1$ \\ ${ }^{1}$ Institute of Biological Sciences, Department of Physiologic Sciences, Federal University of Goiás, \\ Campus Samambaia, 74001-970 Goiânia-GO, Brazil, \\ ${ }^{2}$ Pharmacy Faculty, Federal University of Goiás, Setor Universitário, 74000-000 Goiânia-GO, Brazil.
}

\begin{abstract}
RESUMO: "Efeitos do extrato etanólico das folhas de Lafoensia pacari A. St.-Hil., Lythraceae (pacari), em modelos de dor e inflamação". O pacari (Lafoensia pacari A. St.-Hil., Lythraceae) é uma espécie vegetal nativa do cerrado, o extrato da casca de caule é utilizado popularmente para dores e inflamação, tendo mostrado atividade sedativa. Este trabalho objetivou avaliar os efeitos do extrato etanólico das folhas do pacari (EEFP) como analgésico e antiinflamatório. As atividades analgésica e antiinflamatória foram verificadas em camundongos. O tratamento prévio com EEFP $1,0 \mathrm{~g} / \mathrm{kg}$ mostrou atividade antinociceptiva tanto no método das contorções abdominais induzidas por ácido acético como também no modelo de dor induzida por formalina, tanto na fase neurogênica quanto na fase inflamatória. Os pré-tratamentos com o EEFP reduziram o edema de orelha, induzido por óleo de cróton, de forma dose-dependente. Os testes de atividade no sistema nervoso central mostraram que o extrato não provoca incoordenação motora nem hipnose ou sedação. Os resultados mostram que o EEFP mantém as atividades analgésica e antiinflamatória do extrato das cascas do caule do pacari, sendo que a coleta das folhas favorece a preservação desta espécie nativa do cerrado.
\end{abstract}

Unitermos: Dor, inflamação, extrato das folhas, Lafoensia pacari, Lythraceae.

\begin{abstract}
Lafoensia pacari A. St.-Hil., Lythraceae, popularly known as pacari, is a Cerrado's native specimen; the stem bark extract is used in folk for pain and inflammation, also showing sedating activity. This study aimed to evaluate the analgesic and anti inflammatory activities of ethanol extract from pacari leaves (EEPL). These activities were verified in mice. The previous treatment with EEPL $1.0 \mathrm{~g} / \mathrm{kg}$ showed antinociceptive activity both in the acetic acid-induced writing test and in the formalin-induced model of pain, and in neurogenic and inflammatory phases as well. In the croton oil-induced ear edema, the pre-treatments with EEPL reduced the edema in a dose-dependent manner. Also in the carrageenan-induced peritonitis, the two major doses tested (2.0 and $1.5 \mathrm{~g} / \mathrm{kg}$ p.o.) were able to reduce the leukocyte migration in a dose-dependent manner. The Central Nervous System tests showed that the extract does not elicit uncoordinated motricity, hypnosis or sedating effects. The results showed that EEPL maintains the analgesic and anti-inflammatory effects of the stem bark of pacari, being the collect of leaves more favorable to the preservation of this Cerrado's native specimen.
\end{abstract}

Keywords: Pain, inflammation, leaf extract, Lafoensia pacari, Lythraceae.

\section{INTRODUCTION}

Lafoensia pacari A. St.-Hil. is a shrubby plant, of Lythraceae family, natural of Brazilian savannah, ciliary forest and altitude forest, being present since Amapá to Rio Grande do Sul, and also in Paraguay and Bolivia (Santos, 2006). It is used in folk medicine to treat gastric ulcers and inflammation, wounds, itchiness and for slimming (Tonello, 1997); also there are relates of its use as antithermic, scar healing and tonic (Mundo \& Duarte, 2007).
The stem bark ethanolic extract has shown an expressive anti-inflammatory activity, through inhibition of eosinophilia in Toxocara canis-induced infection, not by an antiparasitary action, but by decreased levels of IL-5, a cytokine involved in differentiation, proliferation and activation of eosinophils (Rogerio et al., 2003). Also it was demonstrated related activity to asthma prevention by reduction of eosinophilia and cytokine expression (IL-4, IL-5 and IL-13) related (Rogerio et al., 2008). Furthermore, an antinociceptive and sedating activity of aqueous extract of pacari's stem bark was also observed 
(Matos et al., 2008).

Phytochemical prospection studies of the hydroalcoholic stem bark extract of pacari indicated the presence of tannins, steroids, triterpene and saponins. It was also verified that ellagic acid is the major compound in the ethanolic extract of stem bark, being the principal responsible for anti-scavenging effects (Solon, 2000), gastric anti-secretive and bactericide (Menezes et al., 2006).

Pacari is actually classified as vulnerable, on risk to be ranking on risk of extinction, once it has been indiscriminately explored by its therapeutic properties, besides the destruction of its habitat (Fachim \& Guarim, 1995). The stem bark collect for therapeutic uses causes plant annealing, which leads it to death (Tonello, 1997).

The aim of this work was to verify if the ethanolic extract of pacari leaves (EEPL) presents analgesic and antiinflammatory activity, in order to suggest this part of the plant to be further used on phytopharm or phytotherapic production. Thus, contributes to cerrado's preservation, which contains this specimen, from the valorization and validation of folk known and the sustainable utilization of this important resource.

\section{MATERIALS AND METHODS}

\section{Plant material}

The Lafoensia pacari A. St.-Hil., Lythraceae, leaves were collected in a modified cerrado region, in Bela Vista city, Goiás, Brazil (837 m, 16 $56^{\circ} 54.2^{\prime \prime} \mathrm{S}, 40^{\circ}$ $55^{\prime} 45.1$ ' W), on May 2007. Samples were authenticated by Dr. José Realino de Paula (Pharmacy Faculty/UFG) and a voucher specimen was deposited at the Federal University of Goiás herbarium ( $\mathrm{n}^{\circ}$ 27031). The leaves were dried at $40{ }^{\circ} \mathrm{C}$ with forced ventilation and powdered in Willey mill. Three samples of extract were prepared by maceration of leaves powder $(15 \%)$ in ethanol $(70 \%)$ for three days, it was filtered, and then, the crude ethanolic extract was concentrated under low pressure. The income was obtained by dry weight method and at time of use, the extract was solubilized in saline solution, at the required concentrations.

\section{Animals}

Male albino Swiss mice (25 to $35 \mathrm{~g}$ ), which were provided by the Central Animal House of Federal University of Goiás (UFG) were used in this study. The animals were maintained under controlled conditions of temperature and light $(12 \mathrm{~h}$ dark/light), with water and food ad libitum, being acclimatized for $72 \mathrm{~h}$ before the beginning of the experiments, in according to SBCAL normatization. All proceedings and experimental models were executed in accordance with the International Guiding Principles for Biomedical Research Involving
Animals from Council for International Organizations of Medical Sciences (CIOMS), 1985. The experimental protocols were approved by Research Ethic Council of Federal University of Goiás.

\section{Drugs}

Acetone (Isofar, Brazil); Carrageenan (Sigma, USA); Croton-oil (Sigma, USA); Dexamethasone (Hipolabor, Brazil); Ethanol 95\% P.A. (Synth, Brazil); Formaldehyde (Synth, Brazil); Glacial acetic acid (Synth, Brazil); Heparin (Hipolabor, Brazil); Indomethacin (Prodome, Brazil); PBS-phosfate solution; Sodium pentobarbital (Cristália, Brazil); Türk solution (Bioshop, Brazil).

\section{Acetic acid-induced abdominal writhings}

Groups of eleven mice were treated with vehicle $(10 \mathrm{~mL} / \mathrm{kg}$, p.o. $)$, or EEPL (1.0 g/ $/ \mathrm{kg}$ p.o. or s.c.), or indomethacin $(10 \mathrm{mg} / \mathrm{kg}$ p.o., used as positive control), according the method described by Hendershot \& Forsaith (1959) and Koster et al. (1959).

\section{Formalin test}

Groups of eleven mice were treated p.o. with vehicle $(10 \mathrm{~mL} / \mathrm{kg})$, or EEPL $(1.0 \mathrm{~g} / \mathrm{kg})$, or indomethacin $(10 \mathrm{mg} / \mathrm{kg}$, used as positive control), according the method described by Hunskar \& Hole (1987).

\section{Croton oil-induced ear edema test}

Groups of nine mice were treated p.o. with vehicle $(10 \mathrm{~mL} / \mathrm{kg})$, or EEPL $(1.0,0.3$ and $0.1 \mathrm{~g} / \mathrm{kg})$, or dexamethasone $2 \mathrm{mg} / \mathrm{kg}$ (used as positive control), according the method described by Zanini et al. (1992).

\section{Carrageenan-induced peritonitis}

Groups of nine mice were treated p.o. with vehicle $(10 \mathrm{~mL} / \mathrm{kg})$, or EEPL $(1.0,1.5$ and $2.0 \mathrm{~g} / \mathrm{kg})$, or dexamethasone $2 \mathrm{mg} / \mathrm{kg}$ (used as positive control), according the method described by Ferrándiz \& Alcaraz (1991).

\section{Central Nervous System Activity}

The methods performed to evaluate CNS activity were standardized on Laboratory of Natural Products Pharmacology, using Diazepam as positive control (Oliveira et al., 2008).

\section{Rota rod test}

Groups of ten mice were treated p.o. with vehicle 
$(10 \mathrm{~mL} / \mathrm{kg})$ or EEPL $(1.0,0.3$ and $0.1 \mathrm{~g} / \mathrm{kg})$ according the method described by Duham \& Miya (1957), and was count the standing time on rota rod and the falls.

\section{Open field test}

This model was performed based on method described by Sielgel (1946) and validated by Archer (1973), with adaptations based on dark-light box proposed by Costall et al. (1989). The animals $(\mathrm{n}=10)$ were treated p.o. with vehicle $(10 \mathrm{~mL} / \mathrm{kg})$, extract (EEPL 1.0, 0.3 and $0.1 \mathrm{~g} /$ $\mathrm{kg}$ ). One hour after the treatments, the mice were conduced, one at time, to an open circular field, divide in thirteen parts with equal area, in dark ambient, with one single lamp above the center of the field. They were observed for $5 \mathrm{~min}$, had being evaluated: exploratory activity (total number of invaded squares and in peripheral and central regions - light and dark, respectively), number of fecal balls, number of rearing and number of grooming.

\section{Pentobarbital-induced sleep}

Groups of nine mice were treated p.o. with vehicle $(10 \mathrm{~mL} / \mathrm{kg})$ or EEPL $(1.0,0.3$ and $0.1 \mathrm{~g} / \mathrm{kg})$ according the method described by Carlini \& Burgos (1979).

\section{Statistical analysis}

The results were demonstrated as mean \pm SEM. The difference among the groups was verified using ANOVA and Kruskall-Wallis. The degree of significance was verified trough Tukey and Dunn tests. Were considered significant values whose $p<0.05$ (Sokal \& Rohlf, 1981).

\section{RESULTS}

\section{Extractive process}

With pacari leaves maceration (10\%) in ethanol/ water $70 \% \mathrm{v} / \mathrm{v}$ it was obtained $35.7 \%$ yield to EEPL, determined by dry weight method.

\section{Acetic acid-induced abdominal writhings}

The leaves ethanolic extract produced a significant reduction in number of acetic acid-induced writhings. The previous treatments $(1 \mathrm{~h})$ with EEPL $1.0 \mathrm{~g} / \mathrm{kg}$ by oral or subcutaneous ways reduced the number of writhings to $67.7 \pm 2.8$ and $35.7 \pm 6.0$, respectively, in relation to control value (vehicle $10 \mathrm{~mL} / \mathrm{kg}$ ) $85.5 \pm 3.7$ (Figure 1).

\section{Formalin test}

The previous treatment $(1 \mathrm{~h})$ with EEPL $1.0 \mathrm{~g} / \mathrm{kg}$ p.o. reduced the licking time (time of licking the limb after intraplantar injection of formalin), as in the neurogenic phase: from control value (vehicle $10 \mathrm{~mL} / \mathrm{kg}$ ) $62.9 \pm 4.8 \mathrm{~s}$ to $47.1 \pm 4.3 \mathrm{~s}$, as in the inflammatory phase: of $109.36 \pm 8.94 \mathrm{~s}$ to $79.1 \pm 5.9 \mathrm{~s}$ (Figure 2 and 3 ).

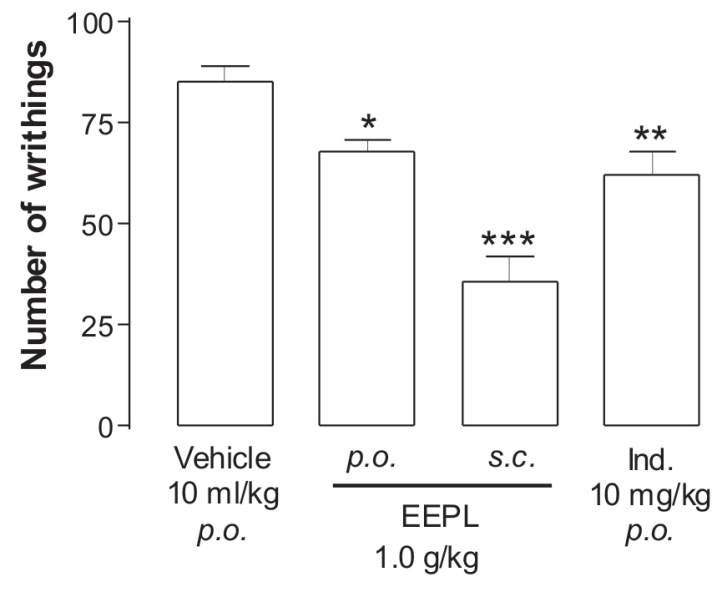

Figure 1. Effects of ethanolic extract of pacari (Lafoensia pacari) leaves (EEPL $1.0 \mathrm{~g} / \mathrm{kg}$ p.o. or s.c.) in the number of acetic acidinduced writhings in mice. Indomethacin $(10 \mathrm{mg} / \mathrm{kg}$ p.o. $)$ was used as positive control. Vertical bars represent mean \pm SEM of cumulated writhings in 30 mins for each experimental group. ${ }^{*} p<0.05 ; * * p<0.01 ; * * * p<0.001$.

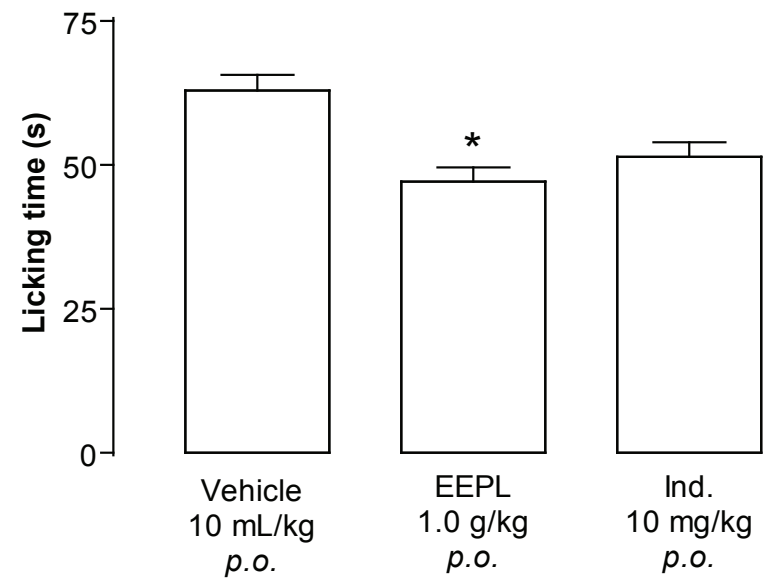

Figure 2. Effects of ethanolic extract of pacari (Lafoensia pacari) leaves (EEPL $1.0 \mathrm{~g} / \mathrm{kg}$ p.o.) and indomethacin (10 mg/kg p.o.) in $1.2 \% \mathrm{v} / \mathrm{v}$ formaline-induced licking time in mice - first phase (0-5 min). Vertical bars represent mean $\pm \mathrm{SEM}$ of pain reaction time, in seconds. ${ }^{*} p<0.05$.

\section{Croton oil-induced ear edema}

The pre treatments with EEPL (1.0, 0.3 and 0.1 $\mathrm{g} / \mathrm{kg}$ p.o.) reduces the edema in a dose-dependent manner, of control value (vehicle $10 \mathrm{~mL} / \mathrm{kg}$ p.o.) $13.11 \pm 0.56 \mathrm{mg}$ to $5.427 \pm 0.36 \mathrm{mg}, 8.37 \pm 0.80 \mathrm{mg}$ and $10.37 \pm 0.86 \mathrm{mg}$, respectively (Figure 4). 


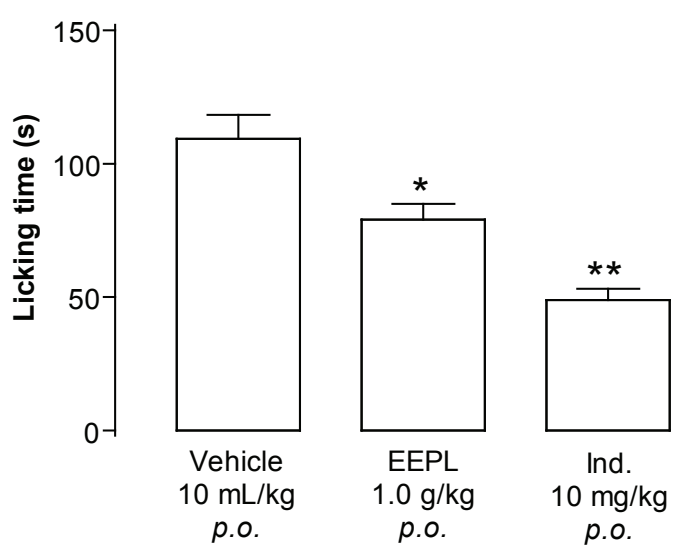

Figure 3. Effects of ethanolic extract of pacari (Lafoensia pacari) leaves (EEPL $1.0 \mathrm{~g} / \mathrm{kg}$ p.o.) in 1,2\% v/v formaline-induced licking time in mice - second phase (15-30 min). Indomethacin $(10 \mathrm{mg} / \mathrm{kg}$ p.o.) was used as positive control. Vertical bars represent mean $\pm \mathrm{SEM}$ of pain reaction time, in seconds. ${ }^{*} p<0.05$; $* * p<0.01$.

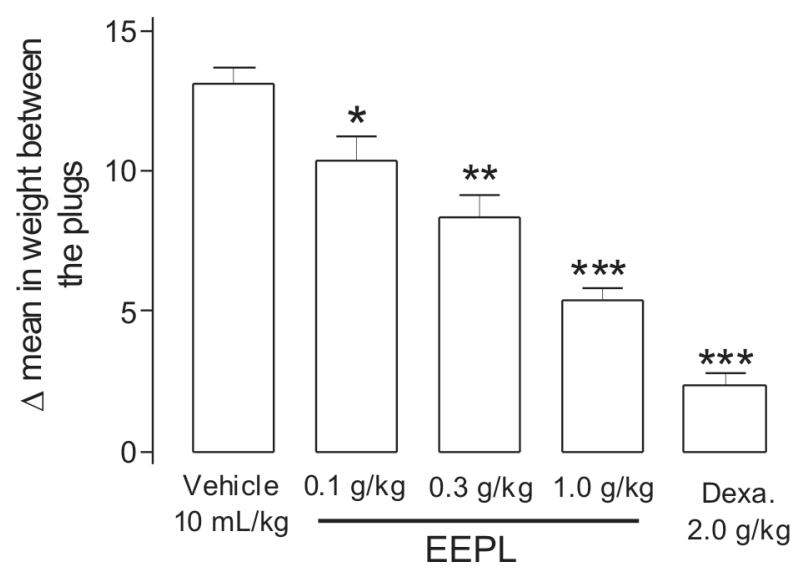

Figure 4. Effects of ethanolic extract of pacari (Lafoensia pacari) leaves (EEPL 1.0, 0.3 and $0.1 \mathrm{~g} / \mathrm{kg}$ p.o.) in croton oilinduced ear edema in mice. Dexamethasone $(2.0 \mathrm{mg} / \mathrm{kg}$ p.o. $)$ was used as positive control. Vertical bars represent mean \pm SEM of difference between left and right ear plugs, in milligrams. ${ }^{*} p<0.05 ;{ }^{*} p<0.01 ; * * * p<0.001$.

\section{Carrageenan-induced peritonitis}

There was significant reduction on the number of migrated leukocytes $/ \mathrm{mL}$ to the abdominal cavity, on the two biggest doses of the extract ( 2.0 and $1.5 \mathrm{~g} / \mathrm{kg}$, p.o. $)$, in a dose- dependent manner, in relation to control value, from $1.22 \pm 0.09 \times 10^{7}$ leukocytes $/ \mathrm{mL}$ (vehicle $10 \mathrm{~mL} / \mathrm{kg}$ v.o.) to $0.7 \pm 0.06 \times 10^{7}$ leukocytes $/ \mathrm{mL}$ (EEPL $2.0 \mathrm{~g} / \mathrm{kg}$ p.o.) and $0.91 \pm 0.06 \times 10^{7}$ leukocytes $/ \mathrm{mL}$ (EEPL $1.5 \mathrm{~g} / \mathrm{kg}$ p.o.). The group treated with smallest dose (EEPL $1.0 \mathrm{~g} / \mathrm{kg}$ ) does not exhibit significant difference, showing value of $1.18 \pm 0.05 \times 10^{7}$ leukocyte/mL (Figure 5).

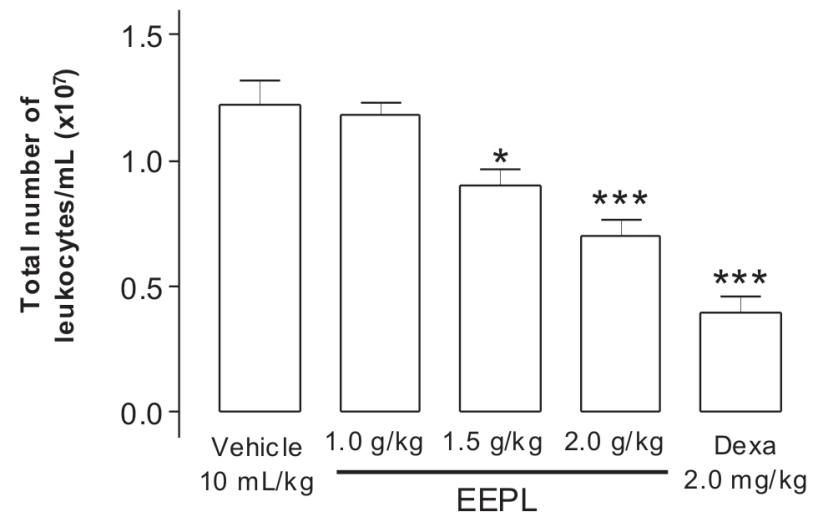

Figure 5. Effects of ethanolic extract of pacari (Lafoensia pacari) leaves (EEPL 1.0, 1.5 and $2.0 \mathrm{~g} / \mathrm{kg}$ p.o.) in carrageenan-induced peritonitis, in mice. Dexamethasone $(2.0 \mathrm{mg} / \mathrm{kg}$ p.o. $)$ was used as positive control. Vertical bars represent mean $\pm \mathrm{SEM}$ of total number of migrated leukocytes/mL. ${ }^{*} p<0.05 ; * * * p<0.001$.

\section{Rota rod test}

The previously treated animals, p.o., with extract (EEPL 1.0, 0.3 and $0.1 \mathrm{~g} / \mathrm{kg}, \mathrm{n}=10$ ) did not showed significant difference on number of falls in rota rod in relation to animals of control group. Also the standing time in the apparatus did not suffer significant difference, from control value (Table 1).

\section{Open field test}

Table 1 shows that previous treatments with EEPL on used doses did not significantly alter the analyzed parameters, in relation to animals treated with vehicle 10 $\mathrm{mL} / \mathrm{kg}$.

\section{Pentobarbital-induced sleep}

The values, in seconds, observed to sleep induction for vehicle and EEPL (1.0, 0.3 and $0.1 \mathrm{~g} / \mathrm{kg}$ ) showed that there is no significant difference in none of the tested doses, when compared to control group (Table 1). The values for sleep recovery, in minutes, for vehicle and EEPL 1.0, 0.3 and $0.1 \mathrm{~g} / \mathrm{kg}$, did not show significant difference too (Table 1).

\section{DISCUSSION}

The antinociceptive effect of ethanolic extract of pacari leaves (EEPL) was shown in two different analgesia models: the acetic acid-induced writhing test and formalin test, in mice. When tissues and cells suffer a noxious stimulus, chemical mediators are released and stimulate C fibers, causing local pain (Driessen, 2007). Acetic acid itself can cause pain, and also stimulates cytokines release (IL- $1 \beta$, TNF- $\alpha$ and IL- 8 ) by macrophages and basophiles 
Table 1. Results of Central Nervous System activity tests: rota rod, open field and pentobarbital-induced sleep, in animals previously treated (p.o.) with vehicle or ethanolic extract of pacari leaves (EEPL $1.0,0.3 \mathrm{and} \quad 0.1 \mathrm{~g} / \mathrm{kg}$ ).

\begin{tabular}{|c|c|c|c|c|}
\hline \multirow{2}{*}{ Parameters } & \multirow{2}{*}{$\begin{array}{c}\text { Vehicle } \\
(10 \mathrm{~mL} / \mathrm{kg})\end{array}$} & \multicolumn{3}{|c|}{ EEPL } \\
\hline & & $1.0 \mathrm{~g} / \mathrm{kg}$ & $0.3 \mathrm{~g} / \mathrm{kg}$ & $0.1 \mathrm{~g} / \mathrm{kg}$ \\
\hline Number of falls on rota rod & $1.0 \pm 0.4$ & $0.3 \pm 0.2$ & $0.2 \pm 0.1$ & $1.5 \pm 0.4$ \\
\hline Standing time on rota rod $(\mathrm{sec})$ & $57.2 \pm 1.9$ & $60.0 \pm 0.0$ & $60.0 \pm 0.0$ & $53.6 \pm 3.4$ \\
\hline Invaded squares (center) & $44.8 \pm 4.82$ & $37.35 \pm 4.81$ & $34.81 \pm 1.90$ & $42.4 \pm 3.94$ \\
\hline Invaded squares (periphery) & $77.3 \pm 6.3$ & $75.4 \pm 9.8$ & $82.0 \pm 8.0$ & $72.9 \pm 5.14$ \\
\hline Fecal balls & $1.7 \pm 0.4$ & $1.5 \pm 0.7$ & $1.2 \pm 0.5$ & $2.3 \pm 0.6$ \\
\hline Rearing & $43.5 \pm 7.3$ & $44.5 \pm 11.5$ & $39.7 \pm 6.2$ & $39.9 \pm 6.4$ \\
\hline Grooming & $2 \pm 0.6$ & $2.7 \pm 0.9$ & $3.5 \pm 0.7$ & $1.4 \pm 0.3$ \\
\hline Induction time to sleep (seconds) & $168.0 \pm 3.4$ & $159 \pm 3.77$ & $165.7 \pm 5.44$ & $176.77 \pm 4.01$ \\
\hline Duration of sleep (minutes) & $75.7 \pm 5.7$ & $93.0 \pm 5.0$ & $60.9 \pm 5.2$ & $80.2 \pm 8.07$ \\
\hline
\end{tabular}

resident in abdominal cavity (Ribeiro et al., 2000). EEPL $1.0 \mathrm{~g} / \mathrm{kg}$ reduced significantly the number of abdominal writhings, mainly the subcutaneous way. However, this way showed toxicity (death), being discarded in subsequent assays.

Recent studies demonstrated that antinociceptive action of the pacari's stem bark aqueous extract, seen in writhing test, is not related to central analgesic activity (Matos et al., 2008).

With relation to licking test, the previous treatment with EEPL $1.0 \mathrm{~g} / \mathrm{kg}$ p.o. promoted significant reduction on the licking time (showed by limb licking), as in the neurogenic phase (first $5 \mathrm{~min}$ after formaline intraplantar injection), as in inflammatory phase (15 to $30 \mathrm{~min}$ after the injection).

In this model, the behavior reaction on first phase can be blocked by drugs with analgesic action similar to kinins antagonists and central opioid analgesics (Barber et al., 1994; Siegmund et al., 1957; Steranka et al., 1987), besides NMDA and vanilloids antagonists (Hunskaar \& Hole, 1987; Shibata et al., 1989) Steroidal and nonsteroidal anti-inflammatories, kinins antagonists and opioids (central and peripheral) inhibits the second phase of formalin test (Hopkins, 2003).

The analgesic activity showed in this work may be independent of anti-inflammatory action and it may involve or not opioid receptor interactions. Preliminary studies have shown that pacari's stem bark ethanolic extract has not interaction with opioid receptors (Nascimento et al., 2008).

In aim to enlighten the mechanism that results in reduction of reactive time to pain on the second phase of formalin test, it was used the croton oil-induced ear edema to evaluate anti-inflammatory activity. The test demonstrated that previous treatment with EEPL reduces the edema in a dose-dependent manner, showing inhibition close to $58.7 \%$ in the highest dose, in comparation with control group.

The pacari's stem bark extract fractionation leads to identification of ellagic acid as the major compound, being the responsible for anti-inflammatory and anti- edematous actions observed in murine model of asthma (Rogerio et al., 2006). Ellagic acid was also identified in Lafoensia pacari leaves trough High Performance Liquid Chromatography (HPLC) (Contin \& Solon, 2004).

Anti-inflammatory action was also showed in carrageenan-induced peritonitis, when it was observed a significant reduction on the number of migrated leukocytes to abdominal cavity in the two bigger doses of extract, in a dose-dependent manner. It's possible that the inhibition of leukocyte migration was due to reduction by ellagic acid in level of some cytokines, especially interleukins, in fact, once demonstrated in other experimental models (Rogerio et al., 2006).

In order to investigate a possible central depressor, sedative or miorelaxant effect of extract in mice (what could interfere in the writhing test), were realized central activity tests: rota rod, open field and pentobarbital-induced sleep tests.

All of them showed no influence of EEPL on central activity on tested doses, what reinforces the safety of its utilization, once does not affect motricity nor causes hypnosis or sedation. Other works have shown the high antioxidant ability of leaves ethanolic extract (Marçal et al., 2004).

The results of this study provide evidences that EEPL maintain analgesic and anti-inflammatory effect observed in stem bark extracts (Matos et al., 2008). The collect of leaves is less damage to preservation of this cerrado's native species, thus, the results not only confirm the folk utilization of this plant, but also give support for propagation of other kind of utilization - ethanolic extract of leaves. In such a manner, avoid the three anneling and, consequently, its degradation.

\section{ACKNOWLEDGEMENTS}

The authors are grateful to Mrs. Ekaterina A. F. B. Rivera and Jackson Nascimento de Lima for ethical and technical assistance in animal proceedings. Thanks also to FUNAPE/UFG, PRPPG/UFG, FAPEG, CAPES and CNPq for financial support. 


\section{REFERENCES}

Archer J 1973. Tests for emotionality in rats and mice: a review. Anim Behav 21: 205-35.

Barber A, Bartoszyk GD, Bender, HM, Gottschlich R, Greiner HE, Harting J, Mauler F, Minck KO, Murray RD, Simon M, Seyfried, CA 1994. A pharmacological profile of he novel peripherally-selective $\kappa$-opioid receptor agonist, EMD 61753. Br J Pharmacol 113: 1317-1327.

Carlini EA, Burgos V 1979. Screening farmacológico de ansiolíticos: metodologia laboratorial e comparação entre o diazepam e o clorobenzapam. Rev Assoc Bras Psiquiatr 3: $25-31$.

Council for International Organizations of Medical Sciences (CIOMS) 1985 - International Guiding Principles for Biomedical Research Involving Animals. Altern Lab Anim 12, n.4.

Contin T, Solon S 2004. Estudo fitoquímico por CLAE das folhas de Lafoensia pacari St. Hil. (Lythraceae). In: Encontro de Produção Científica do Curso de Farmácia. Resumos. Campo Grande: UNIDERP, p. 27.

Costall B, Kelly ME, Naylor RJ, Onaivi ES 1989. The actions of nicotine and cocaine in a mouse model of anxiety. Pharmacol Biochem Behav 33:197-203.

Driessen B 2007. Pain: from sign to disease. Clin Tech Equine Pract 6: 120-125.

Duham NW, Miya TS 1957. A note on a simples apparatus for detecting neurological deficit in rats and mice. $J$ Amer Pharm Assoc 46: 208-209.

Fachim E, Guarim VLMS 1995. Conservação da biodiversidade: espécies da flora de Mato Grosso. Acta Bot Bras 9: 281302.

Ferrándiz ML, Alcaraz MJ 1991. Anti-inflammatory activity and inhibition of arachidonic acid metabolism by flavonoids. Agents Actions 32: 283-288.

Hendershot LC, Forsaith J 1959. Antagonism of the frequency of phenylquinone-induced writhing in the mouse by weak analgesics and nonanalgesics. J Pharmacol Exp Therap 125: $237-240$.

Hopkins SJ 2003. The pathophysiological role of cytokines. Legal Medicine 5: 45-57.

Hunskar S, Hole K 1987. The formalin test in mice: dissociation between inflammatory and non-inflammatory pain. Pain 30: 103-14.

Koster R, Anderson M, Beer EJ 1959. Acetic acid for analgesic screening. Fed Proc 18: 412.

Marçal F, Fratin LC, Pereira ROS, Solon S 2004. Capacidade antioxidante dos extratos secos de Bixa orellana L. (semente), Pfaffia glomeratta (raiz) e Lafoensia pacari (folha). In: Encontro de Produção Científica do Curso de Farmácia. Resumos. Campo Grande: UNIDERP, p. 16.

Matos LG, Santos SR, Ferreira RN, Pontes IS, Paula JR, Costa EA 2008. Anti-inflammatory, antinociceptive and sedating effects of Lafoensia pacari aqueous extract. Pharm Biol 46: 341-346.

Menezes VM, Atallah AN, Lapa AJ, Catapani WR 2006. Assessing the therapeutic use of Lafoensia pacari St. Hil. extract (mangava-brava) in the eradication of Helicobacter pylori: double-blind randomized clinical trial. Helicobacter 11: 188-195.

Mundo SR, Duarte MR 2007. Morfoanatomia foliar e caulinar de dedaleiro: Lafoensia pacari A. St.-Hil. (Lythraceae). Lat Am J Pharm 26: 522-9.
Nascimento MVM, Galdino PM, Tavares A, Barbosa DBR, Paula JR de, Costa EA 2008. Fracionamento biomonitorado pela atividade analgésica do extrato etanólico da casca do caule de Lafoensia pacari St.-Hil. (Pacarí). In: III Reunião Regional da FeSBE. Anais. Goiânia: FeSBE, n. 36,004 .

Oliveira RB, Nascimento MVM, Valadares MC, Paula JR, Costa EA, Cunha LC 2008. Avaliação dos efeitos depressores centrais do extrato etanólico das folhas de Synadenium umbellatum Pax. e de suas frações em camundongos albinos. Rev Bras Cienc Farm 44: 485-491.

Ribeiro RA, Vale ML, Thomazzi SM, Paschoalato AB, Poole S, Ferreira SH, Cunha FQ 2000. Involvement of resident macrophages and mast cells in the writhing nociceptive response induced by zymosan and acetic acid in mice. Eur J Pharmacol 387: 111-18.

Rogerio AP, Sá-Nunes A, Albuquerque DA, Anibal FF, Medeiros AI, Machado ER, Souza AO, Prado Jr JC, Faccioli LH 2003. Lafoensia pacari extract inhibits IL-5 production in toxocariasis. Parasite Immunol 25: 393-400.

Rogerio AP, Fontanari C, Melo MC, Ambrosio SR, Souza GE, Pereira PS, Franca SC, Costa FB, Albuquerque DA, Faccioli LH 2006. Anti-inflammatory, analgesic and anti-oedematous effects of Lafoensia pacari extract and ellagic acid. J Pharm Pharmacol 58: 1265-73.

Rogerio AP, Fontanari C, Borducchi E, Keller AC, Rosso M, Soares EG, Albuquerque DA, Faccioli LH 2008. Antiinflammatory effects of Lafoensia pacari and ellagic acid in a murine model of asthma. Eur J Pharmacol 508: 262270.

Santos LW 2006. Estudos ecológicos e agronômicos de Lafoensia pacari St. Hil. (LYTHRACEAE) na região de Barra do Garças - MT. Cuiabá, Brasil, MSc Thesis, Faculdade de Agronomia e Medicina Veterinária da Universidade Federal do Mato Grosso, Cuiabá, 60 pp.

Shibata M, Ohkubo T, Takahashi H, Inoki R 1989. Modified formalin test: characteristic biphasic pain response. Pain 38: 347-52.

Siegmund E, Cadmus R, Lu G 1957. Method for the evaluation of both non-narcotic and narcotic analgesics. Proc Soc Exp Biol Med 95: 728-729.

Sielgel PS 1946. A simple electronic device for the measurement of gross bodily activity of small animals. J Psychol 21: 227-236.

Sokal RR, Rohlf FJ 1981. Biometry, the principles and practice of statistics biological research. 2nd. ed., W.H. Freeman and Company, San Francisco, 587 pp.

Solon S, Lopes L, Sousa Jr PT, Schmeda-Hirschmann, G 2000. Free radical scavenging activity of Lafoensia pacari. $J$ Ethnopharmacol 72: 173-178.

Steranka LR, DeHaas CJ, Vavrek RJ, Stewart JM, Enna SJ, Snyder SH 1987. Antinociceptive effects of bradykinin antagonists. Eur J Pharmacol 36: 261-262.

Tonello VM 1997. Estrutura de populações de Lafoensia pacari St. Hil. e dados etnobotânicos e fenológicos em Nossa Senhora do Livramento-MT, MSc Thesis, Universidade Federal de Mato Grosso, Cuiabá, Brasil, 94 pp.

Zanini JC Jr, Medeiros YS, Cruz AB, Yunes RRA, Calixto JB 1992. Action of compounds from Mandevilla velutina on croton oil-Induced ear edema in mice: a comparative study with steroidal and nonsteroidal antiinflammatory drugs. Phytother Res 6: 1-5. 